\title{
Effect of Bacillus aryabhattai H26-2 and B. siamensis H30-3 on Growth Promotion and Alleviation of Heat and Drought Stresses in Chinese Cabbage
}

\author{
Da Jeong Shin ${ }^{1}$, Sung-Je Yoo ${ }^{1,2}$, Jeum Kyu Hong ${ }^{3}$, Hang-Yeon Weon ${ }^{1}$, Jaekyeong Song ${ }^{1}$, and \\ Mee Kyung Sang (D) 1* \\ ${ }^{I}$ Division of Agricultural Microbiology, National Institute of Agricultural Science, Rural Development Administration, \\ Wanju 55365, Korea \\ ${ }^{2}$ Department of Agbiotechnology and Natural Resources, Gyeongsang National University, Jinju 52828, Korea \\ ${ }^{3}$ Department of Horticultural Science, Gyeongnam National University of Science and Technology (GNTech), 33 \\ Dongjin-ro, Jinju 52725, Korea
}

(Received on August 9, 2018; Revised on December 4, 2018; Accepted on December 18, 2018)

Plants are exposed to biotic stresses caused by pathogen attack and complex abiotic stresses including heat and drought by dynamic climate changes. To alleviate these stresses, we investigated two bacterial stains, H26-2 and H30-3 in two cultivars ('Ryeokkwang' and 'Buram-3-ho') of Chinese cabbage in plastic pots in a greenhouse. We evaluated effects of bacterial strains on plant growth-promotion and mitigation of heat and drought stresses; the role of exopolysaccharides as one of bacterial determinants on alleviating stresses; biocontrol activity against soft rot caused by Pectobacterium carotovorum subsp. carotovorum PCC21. Strains H26-2 and H30-3 significantly increased fresh weights compared to a $\mathrm{MgSO}_{4}$ solution; reduced leaf wilting and promoted recovery after re-watering under heat and drought stresses. Chinese cabbages treated with H26-2 and H30-3 increased leaf abscisic acid (ABA) content and reduced stomatal opening after stresses treatments, in addition, these strains stably colonized and maintained their populations in rhizosphere during heat and drought stresses. As well as tested bacte-

\footnotetext{
*Corresponding author.

Phone) +82-63-238-3055, FAX) +82-63-238-3834

E-mail)mksang@korea.kr

ORCID

Mee Kyung Sang

https://orcid.org/0000-0001-9032-7012

(c) This is an Open Access article distributed under the terms of the Creative Commons Attribution Non-Commercial License (http:// creativecommons.org/licenses/by-nc/4.0) which permits unrestricted noncommercial use, distribution, and reproduction in any medium, provided the original work is properly cited.
}

Articles can be freely viewed online at www.ppjonline.org. rial cells, exopolysaccharides (EPS) of H30-3 could be one of bacterial determinants for alleviation of tested stresses in Chinese cabbages, however, the effects were different to cultivars of Chinese cabbages. In addition to bacterial activity to abiotic stresses, $\mathrm{H30-3}$ could suppress incidence (\%) of soft rot in 'Buram-3-ho'. The tested strains were identified as Bacillus aryabhattai H26-2 and $B$. siamensis $\mathrm{H30-3}$ based on 16S rRNA gene sequence analysis. Taken together, $\mathrm{H26-2}$ and H30-3 could be candidates for both plant growth promotion and mitigation of heat and drought stresses in Chinese cabbage.

Keywords : abiotic stress, exopolysaccharide, soft rot

Handling Editor : Lee, Yong Hoon

Plants frequently face adverse climates and environmental factors including extreme temperatures (heat, cold, and freezing), drought and salinity; these are the major abiotic stresses that limit plant growth, development, and crop yield. In particular, heat and water deficit are the main environmental stress factors and these two different stresses can occur simultaneously in fields (Dobra et al., 2010). When plants are exposed to stressful conditions, they often respond to the stress by producing ethylene. Stress-induced ethylene can inhibit plant growth and root elongation as well as trigger plant senescence and chlorosis, ultimately leading to death (Barnawal et al., 2014). Agrochemicals, such as aminoethoxyvinylglycine (AVG), $\mathrm{Co}^{2+}$, and $\mathrm{Ag}^{+}$, are used as inhibitors of ethylene formation or action, increasing plant growth under abiotic stress (Belimov et al., 
2009). However, these ethylene inhibitors are high-priced, are toxic to humans, and impair soil health. Therefore, alternative approaches, including plant-rhizobacteria interactions to alleviate abiotic stresses in plants, have been studied (Belimov et al., 2009; Dimkpa et al., 2009).

Plant-associated bacteria have been used in sustainable agricultural system, especially, plant growth-promoting rhizobacteria (PGPR) have an effect on plant growth and development by production of (i) phytohormones such as indole-3-acetic acid (IAA), abscisic acid (ABA), cytokinins, and gibberellic acid; (ii) volatile compounds; and (iii) bacterial exopolysaccharides (EPS) (Sang et al., 2018; Timmusk et al., 2014; Vurukonda et al., 2016); many PGPR are well known to suppress plant disease as biotic stresses by induced resistance (Yang et al., 2009). The beneficial effect of plant-associated bacteria including PGPR is not limited to induced tolerance to biotic stresses but extends to abiotic stresses (Kaushal and Wani, 2016; Yang et al., 2009). However, the agricultural uses of plant-associated bacteria against abiotic stresses remain largely uncommon compared to PGPR and biocontrol against biotic stresses.

Chinese cabbage (Brassica campestris spp. pekinensis) is one of the most important vegetables in Asia, especially, Korea, China, and Japan. In Korea, commercial Chineses cabbage cultivars were separated by sowing seasons, such as 'Ryeokkwang' as a spring cultivar and 'Buram-3-ho' as a fall cultivar; largely mass consumption of Chinese cabbage occurred in fall-early winter season. Recently, heat and drought conditions by dynamic global climate changes occur at the same times in Korea, it frequently causes serious problems in Chinese cabbage fields during the growing season, causing the productivity of Chinese cabbage to fluctuate and be unstable (Kim et al., 2010).

Here, we investigated effect of bacterial strains on plant growth promotion and mitigation of concurrent stresses including heat and drought in Chinese cabbages; we demonstrated physiological changes in leaves of Chinese cabbages, and bacterial colonization of the rhizosphere during heat and drought stresses. In addition, we determined whether bacterial EPS can promote plant growth and alleviate heat and drought stresses; finally, we evaluated biocontrol activity against bacterial soft rot in two cultivars of Chinese cabbages; identified strains H26-2 and H30-3 based on 16S rRNA sequence analysis.

Bacterial strains were isolated from the rhizospheres of cucumber and Chinese cabbage in Korea. The sampled soils were suspended in $0.85 \% \mathrm{NaCl}$ solution for $30 \mathrm{~min}$ at $28^{\circ} \mathrm{C}$ and incubated on Reasoner's $2 \mathrm{~A}$ (R2A) agar (Lab M Ltd., UK) amended with $50 \mu \mathrm{g} / \mathrm{ml}$ of cycloheximide for $3 \mathrm{~d}$ at $28^{\circ} \mathrm{C}$. A total 46 strains were collected, two strains
(H26-2 and H30-3) among these were selected based on alleviating effect on heat and drought stresses in our preliminary test (Supplementary Fig. 1). Bacterial strains were stored in vials containing tryptic soy broth (TSB, Difco, USA) amended with $20 \%$ glycerol and stored at $-80^{\circ} \mathrm{C}$ before use. For the preparation of bacterial suspensions, two strains were grown on tryptic soy agar (TSA, Difco, USA) at $28^{\circ} \mathrm{C}$ for $48 \mathrm{~h}$ and then single colonies were cultured in 250-ml Erlenmeyer flasks containing $100 \mathrm{ml}$ of TSB in a rotary shaking incubator $(150 \mathrm{rpm})$ at $28^{\circ} \mathrm{C}$ for $48 \mathrm{~h}$. Bacterial cells were harvested by centrifugation at $5,000 \mathrm{rpm}$ for $10 \mathrm{~min}$ and suspended in $10 \mathrm{mM} \mathrm{MgSO} 4$ solution. The bacterial suspensions were adjusted to $10^{7}$ cells $/ \mathrm{ml}$ with a UV/VIS spectrophotometer (Infinite M200 PRO, TECAN, Austria) and used for further tests.

For in vitro assay for bacterial plant growth-promoting (PGP) traits, bacterial ACC deaminase activity was evaluated by the method of Penrose and Glick (2003) and Khandelwal and Sindhu (2013); phosphate solubilization by bacterial strains was measured onto PVK agar amended with bromophenol blue (Pikovskaya, 1948); bacterial IAA production was assayed according to methods of Bric et al. (1991) and Kumar et al. (2012). Bacterial EPS production was determined on a TSA plate by observation of a slimy colony morphology (Tallgren et al., 1999). In addition, siderophore production was detected on chrome azurol S (CAS) agar plate assay (Milagres et al., 1999); hydrogen cyanide $(\mathrm{HCN})$ production was measured on TSA (Castric and Castric, 1983). These bacterial biological traits were measured as positive or negative reactions.

For assessment of growth promotion activity, two cultivars of Chinese cabbage ('Ryeokkwang', NongWoo Bio Ltd, Suwon, Korea and 'Buram-3-ho', Farm Hannong Co., Ltd, Gyeonggi-do, Korea) were used. Chinese cabbage seeds were sown into plastic pots (diameter $9 \mathrm{~cm}$ ) containing commercial potting mixture (Bunong, Korea) and grown in a greenhouse. Seedlings (four-leaf stage) were drenched with bacterial suspensions of H26-2 and H30-3 (10 cells $/ \mathrm{ml}, 1 \mathrm{ml} / \mathrm{g}$ of potting mixture) or a $10 \mathrm{mM}$ $\mathrm{MgSO}_{4}$ solution as untreated control in a greenhouse. Two weeks after the drench treatment, the fresh weights of the Chinese cabbages (six $\sim$ seven-leaf stages) were measured. For test of bacterial-mediated alleviation of abiotic stresses (heat and drought), bacterial suspensions and plant materials were prepared according to the methods described above. One week after bacterial drench treatment, plants were uniformly watered with $20 \mathrm{ml}$ tap water and then heat and drought stressed by withholding watering for 5-7 $\mathrm{d}$ at $35^{\circ} \mathrm{C}$ in a growth chamber ( $16 \mathrm{~h}$ fluorescent light $/ \mathrm{d}, 40 \%$ relative humidity). Pot positions were randomly changed 
every day. When the control had wilted $60-80 \%$, the wilting of plants was assessed using a leaf wilting score (LWS) based on relative water contents (RWC, \%) (Barrs and Weatherley, 1962): score $0,100 \% ; 1,80-100 \% ; 2,60-80 \%$; 3, 40-60\%; 4, 20-40\%; and 5, 0-20\% RWC. The stress treatment was terminated by drenching with $40 \mathrm{ml}$ of sterile water (re-watering). Twenty-four $\mathrm{h}$ later, fresh weight $(\mathrm{g})$ were evaluated. This experiment was conducted twice with ten replicates each.

For quantification of ABA in Chinese cabbage leaves, plant materials and bacterial suspension were prepared; heat and drought stresses were performed as described above. Leaves were sampled $24 \mathrm{~h}$ after stresses treatment, and then, ABA content was measured using the Phytodetek competitive ELISA kit (Agdia, Elkhart, IN, USA). At the same time, stomatal opening was observed using light microscopy (Zeiss Model, Germany) (Jung et al., 2000). At least 100 stomata per plant were counted. This experiment was conducted twice with four (for ABA contents), and eight (for stomatal opening) replicates each.

Bacterial colonization in rhizosphere soils of Chinese cabbage under heat and drought conditions was evaluated by using spontaneous rifampicin-resistant mutants of H262 (H26-2 Rif) and H30-3 (H30-3 Rif) (10 cells $/ \mathrm{ml}, 1 \mathrm{ml} /$ g) (Sang and Kim, 2012). Bacterial suspensions of H262 Rif and H30-3 Rif were drenched into Chinese cabbages (four-leaf stage), one week later, pots were transferred to a growth chamber for heat and drought stresses induced by withholding watering for $5 \mathrm{~d}$ at $35^{\circ} \mathrm{C}$. The rhizosphere soil was collected 1,3 , and $5 \mathrm{~d}$ after stresses (DAS) treatment. Rhizosphere soil ( $1 \mathrm{~g}$ ) was put into a $15-\mathrm{ml}$ tube with $10 \mathrm{mM} \mathrm{MgSO}_{4}$ solution and then incubated at $120 \mathrm{rpm}$ at $28^{\circ} \mathrm{C}$ for $1 \mathrm{~h}$. Soil suspensions were serially diluted on rifampicin $(100 \mu \mathrm{g} / \mathrm{ml})$-supplemented TSA (RTSA), incubated at $28^{\circ} \mathrm{C}$ for $48 \mathrm{~h}$, and colony forming units (cfu) was counted. At the same time, bacterial colonization under non-stress conditions was tested. This experiment was conducted twice with four replicates each.

To assess whether EPS of H26-2 and H30-3 were one of bacterial determinant for growth promotion and mitigation heat and drought stresses in Chinese cabbages, EPS were extracted from the strains (Santaella et al., 2008). For in plate assay, seeds of two Chinese cabbage cultivars were surface-sterilized with $2 \% \mathrm{NaOCl}$ for 2 min and rinsed with sterile distilled water three times. Sterile seeds were transferred to plates (height $4 \mathrm{~cm}$ ) containing MS media amended with $400 \mathrm{mM}$ mannitol, as an artificial drought treatment, and EPS $(10 \mu \mathrm{g} / \mathrm{ml})$ of H26-2 and H30-3. They were then kept at $25^{\circ} \mathrm{C}$ and $16 \mathrm{~h}$ fluorescent light per $\mathrm{d}$. The number of cotyledon with open and green leaves after seed germination and number of lateral root was recorded at 3-4 and $17 \mathrm{~d}$, respectively. This experiment was conducted twice with ten replicates each. In planta, seedlings (four-leaf stage) were drenched with an EPS solution (10 $\mu \mathrm{g} / \mathrm{ml}$ ) of H26-2 and H30-3 or with distilled water as the control. One week later, pots were transferred to heat and drought stresses conditions in a growth chamber as described above. Then, leaf wilting scores and fresh weights were measured; at the same time, a non-stress condition was tested. This experiment was conducted twice with eight replicates each.

For test of biocontrol activity of two bacterial strains against soft rot in Chinese cabbages, preparation of plants and bacterial suspensions were conducted as descried above. Benzothiadiazole (BTH, $0.1 \mathrm{mM}$ ) was used as a chemical control. For plant inoculation, P. carotovorum subsp. carotovorum PCC21 was cultured in $50 \mathrm{ml}$ of LuriaBertani (LB) broth at $28^{\circ} \mathrm{C}, 160 \mathrm{rpm}$ for $24 \mathrm{~h}$, and then diluted to $\mathrm{OD}_{600}=0.1$. One week after bacterial treatment, two cultivars of Chinese cabbages were drenched by a $4: 1$ mixture of PCC21 and sterile mineral oil (heavy white oil, sigma) (Lee and Cha, 2001), and disease incidence (\%) was determined 10-15 $\mathrm{d}$ after inoculation. This experiment was conducted twice with three replicates with 15 seedlings each.

Bacterial identification was conducted by $16 \mathrm{~S}$ rRNA gene sequencing using the universal primers $\mathrm{fD} 1$ (5'-AGAGTTTGATCCTGGCTCAG-3') and rP2 (5'-ACGGCTACCTTGTTACGACTT-3') (Weisburg et al., 1991). Polymerase chain reaction (PCR), DNA sequencing, and phylogenetic analyses were conducted as described by Kim et al. (2009). The 16S rRNA gene sequence of H26-2 (1,511 base pairs, bp) and H30-3 (1,381 bp) were analyzed and compared with related type species within the Bacillus genus using EzBioCloud (Yoon et al., 2017).

All experiments were performed as completely randomized designs. Statistical analysis of the data was conducted using Statistical Analysis Systems 9.02 software (SAS Institute, Cary, NC). Data from repeated experiments were pooled after confirming the homogeneity of variances with Levene (1960) test and were further statistically analyzed. The microbial cfu data were analyzed after logarithmic transformation. Analysis of variance was determined using the general linear model procedure. Means were separated using the least significant difference test at $P<0.05$.

In our present study, we evaluated the effects of bacterial strains on growth promotion and mitigation of heat and drought stresses in Chinese cabbage plants. Strains H262 and H30-3 were selected from 46 strains, whereas $B$. vallismortis BS07M (Bacillo V3, NAPROBIOTEC Inc., 

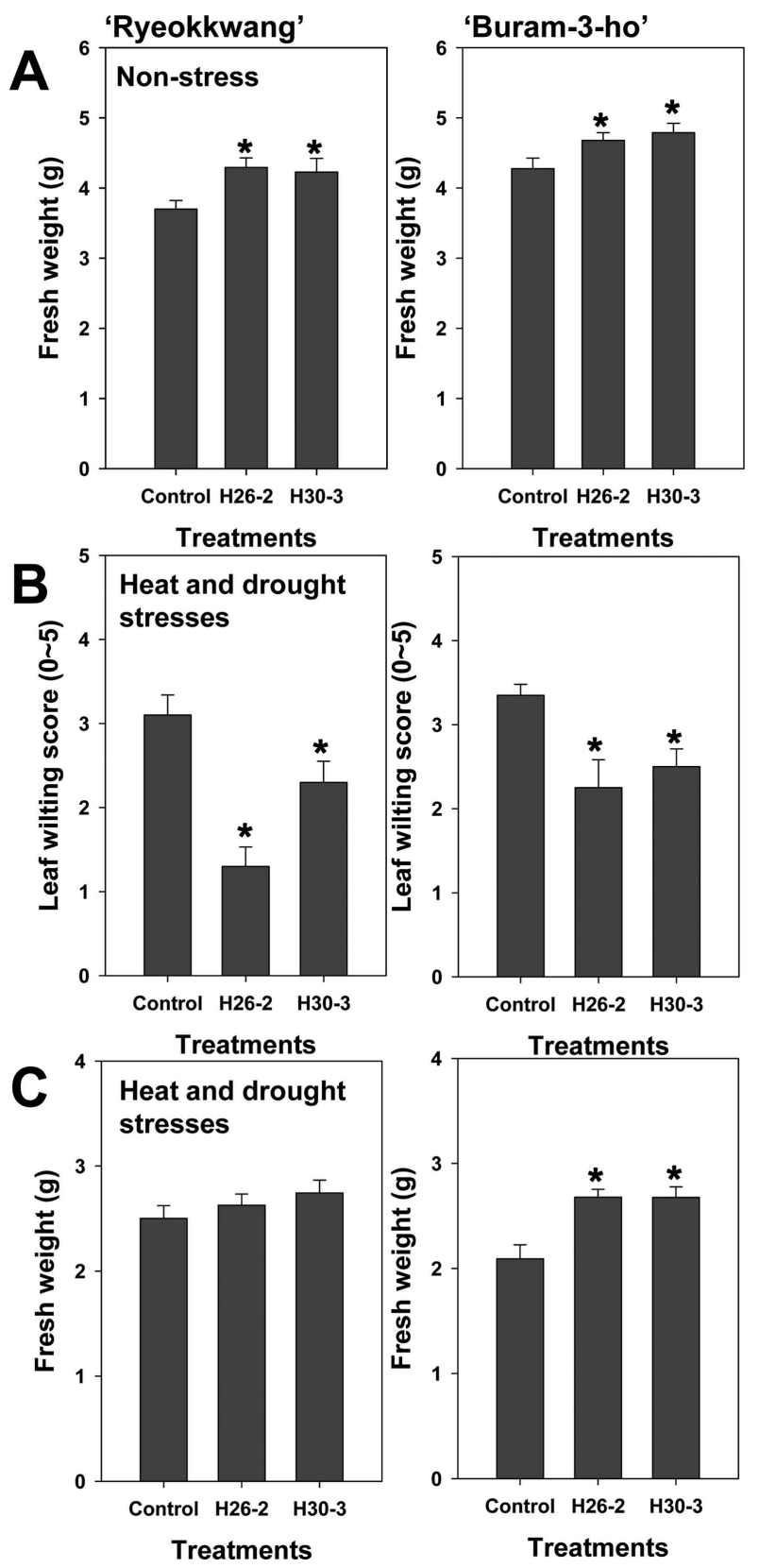

Fig. 1. (A) Growth promotion by Bacillus aryabhattai H26-2 and Bacillus siamensis $\mathrm{H} 30-3$ compared to $10 \mathrm{mM} \mathrm{MgSO}_{4}$ solution (control) in Chinese cabbage ('Ryeokkwang' and 'Buram3-ho') under non-stress condition; (B) Leaf wilting score (05) under heat and drought conditions; (C) fresh weight after rewatering of Chinese cabbages ('Ryeokkwang' and 'Buram-3ho'). Plants were treated with bacterial strains H26-2 and H303 , or $10 \mathrm{mM} \mathrm{MgSO}_{4}$ solution (untreated control), one week later, heat and drought stresses were treated; Twenty-four $h$ after end of stress treatment, fresh weight were assessed. Error bars indicate the standard errors of 20 replications from two experiments. An asterisk on bars with standard errors indicate significant $(P<0.05)$ differences between treatments according to the least significant difference test. plant immune enhancer) was not appropriate as a positive control for alleviation of heat and drought stresses in Chinese cabbage (Supplementary Fig. 1), therefore we tested two strains for our further studies. Strains H26-2 and H303 had in vitro plant growth-promoting (PGP) traits including ACC deaminase activity, phosphate solubilization, production of indoleacetic acid, and EPS (data not shown). Moreover, strains H26-2 and H30-3 produced siderophore on CAS agar plates; but these strains did not produce $\mathrm{HCN}$ on TSA.

When strains H26-2 and H30-3 were applied to two cultivars of Chinese cabbage, these strains significantly $(P<$
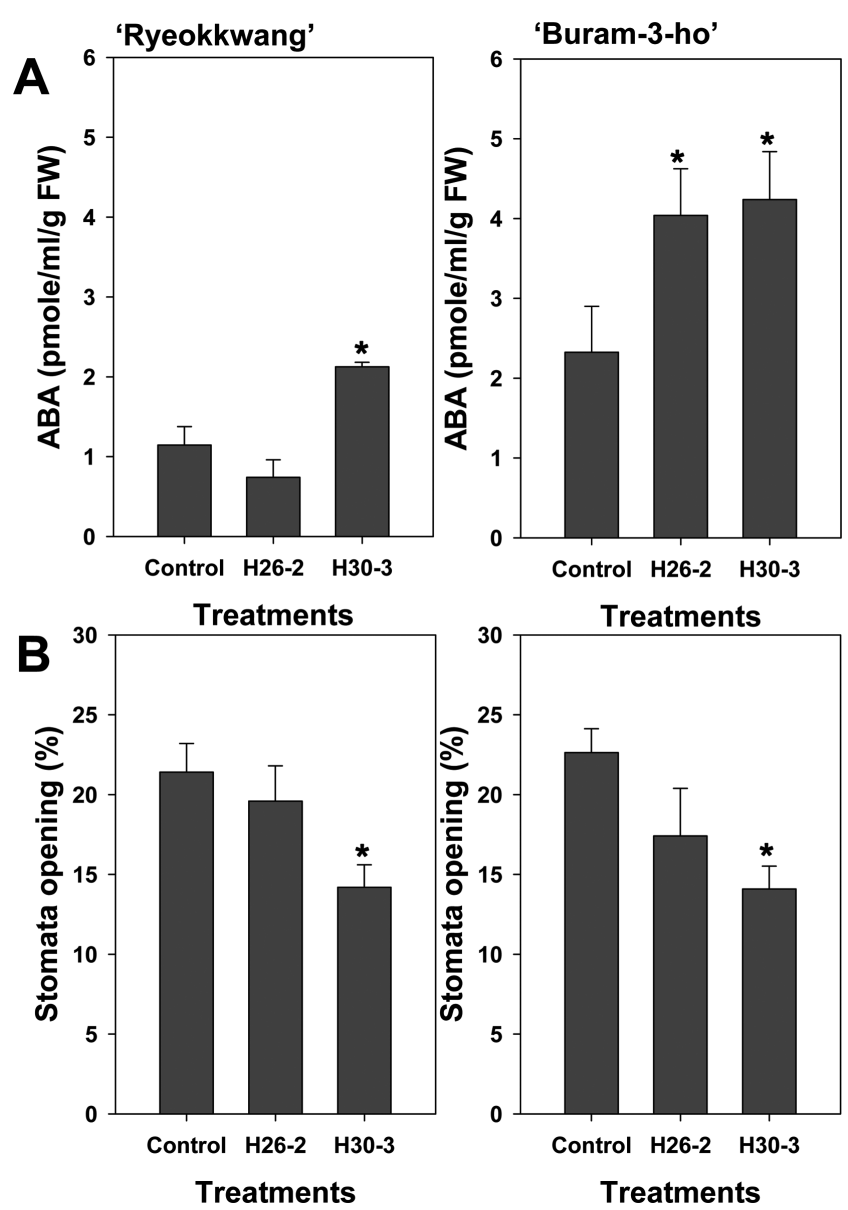

Fig. 2. (A) Abscisic acid (ABA) contents and (B) stomatal opening (\%) in leaves of Chinese cabbages ('Ryeokkwang' and 'Buram-3-ho') at $24 \mathrm{~h}$ after heat and drought stresses treatment. Plants were drenched with strain $\mathrm{H} 26-2$ and $\mathrm{H} 30-3$, and $10 \mathrm{mM}$ $\mathrm{MgSO}_{4}$ solution as untreated control, one week later, heat and drought stresses were performed. Error bars indicate the standard errors of eight (for ABA contents) or 16 (for stomatal opening) replications from two experiments. An asterisk on bars with error bars indicate significant $(P<0.05)$ differences between treatments according to the least significant difference test. 
0.05) increased fresh weight of Chinese cabbage in both cultivars ('Ryeokkwang' and 'Buram-3-ho') compared to the control under non-stressed condition (Fig. 1A). Under heat and drought conditions, cultivar ('Ryeokkwang' and 'Buram-3-ho) and treatment (Control, H26-2 and H30-3) showed significant difference at $P=0.0195$ and $P<0.0001$, respectively. In 'Ryeokkwang', strains H26-2 and H303 significantly $(P<0.05)$ reduced leaf wilting compared to the control (Fig. 2B), while there was no difference in fresh weight $24 \mathrm{~h}$ after re-watering (Fig. 2C). In 'Buram3-ho', tested two strains significantly $(P<0.05)$ reduced leaf wilting (Fig. 2B) and promote recovery compared to a control (Fig. 2C). These results implied two strains could be involved in both PGP and amelioration of abiotic stresses including heat and drought in Chinese cabbages. Some plant-associated bacteria are known as improving crop growth and development under unfavorable single stress including drought or saline soils (Kang et al., 2014; Singh and Jha, 2016). Bresson et al. (2013) and Ghosh et al. (2017) found that PGPR strain Phyllobacterium brassicacearum STM196 and Pseudomonas putida alleviates drought stress, respectively.

To understand the effects of the two strains on the regulation of water content in plants, we measured ABA content and stomatal opening in plant leaves under heat and drought stresses. Abscisic acid in leaves of Chinese cabbage treated with strain H30-3 was significantly $(P<$ $0.05)$ higher than in the control $24 \mathrm{~h}$ after the beginning of stresses in both cultivars (Fig. 2A). Strain H26-2 also showed significantly $(P<0.05)$ higher ABA content in leaves of 'Buram-3-ho'. Based on stomatal observations, strain H30-3 reduced stomatal opening compared to the control $24 \mathrm{~h}$ after stresses in both cultivars (Fig. 2B). On the other hand, stomatal opening (\%) of H26-2 in leaves showed a decreased tendency; however, there was no statistically significant difference compared to the control (Fig. 2B). ABA is widely known as a stress hormone because of its rapid accumulation in plants and its role as a mediator under stress conditions. Under salinity and drought stresses, ABA helps to maintain the water status of plants by regulating guard cells and leaf growth and inducing expression of genes encoding enzymes and proteins related to dehydration tolerance (Zhang et al., 2006; Zhang et al., 2010; $\mathrm{Zhu}, 2002)$. Considering our present results regarding ABA contents and stomatal observation in plants, strains H262 and H30-3 induce the accumulation of ABA and it leads to water control in tested plants by regulation of stomatal opening under abiotic stresses.

Bacterial colonization and population maintainability in rhizosphere soils under unfavorable conditions can be important factors involved in plant-microbe-environmental interactions (Sandhya et al., 2009; Sherameti et al., 2008). When bacterial colonization in rhizosphere of Chinese cabbages was monitored during heat and drought stresses, strains H26-2 Rif and H30-3 Rif colonized the rhizosphere of both cultivars in Chinese cabbages, the bacterial colonization did not affect by days after stresses during stresses in both cultivar's rhizosphere (Table 1). Similarly, under non-stress conditions, colonization of H26-2 Rif and H303 Rif in rhizosphere soils did not change over the entire tested period, except for H26-2 Rif in 'Buram-3-ho' at 5 $\mathrm{d}$ (Table 1). According to comparison between non-stress and stresses, in 'Ryeokkwang', strain H26-2 Rif showed a higher colonization at 1 DAS under stress conditions

Table 1. Bacterial colonization in rhizosphere soils of Chinese cabbages treated with spontaneous rifampicin-resistant mutants, H26-2 Rif and H30-3 Rif under normal and stressed conditions

\begin{tabular}{|c|c|c|c|c|c|}
\hline \multirow{3}{*}{ Cultivars } & \multirow{3}{*}{$\mathrm{DAS}^{\mathrm{a}}$} & \multicolumn{4}{|c|}{ Bacterial colonization $\left[\mathrm{Log}(\mathrm{cfu} / \mathrm{g} \text { of soils })^{\mathrm{b}}\right.$} \\
\hline & & \multicolumn{2}{|c|}{ H26-2 Rif } & \multicolumn{2}{|c|}{ H30-3 Rif } \\
\hline & & Non-stress & Stresses & Non-stress & Stresses \\
\hline \multirow[t]{3}{*}{ Ryeokkwang } & 1 & $4.83 \pm 0.19 \mathrm{a}^{\mathrm{c}}$ & $5.33 \pm 0.11 \mathrm{~A}^{*}$ & $4.26 \pm 0.22 \mathrm{a}$ & $4.00 \pm 0.01 \mathrm{~A}$ \\
\hline & 3 & $4.85 \pm 0.20 \mathrm{a}$ & $4.96 \pm 0.13 \mathrm{~A}$ & $3.66 \pm 0.08 \mathrm{a}$ & $4.01 \pm 0.08 \mathrm{~A}^{*}$ \\
\hline & 5 & $4.74 \pm 0.19 \mathrm{a}$ & $4.98 \pm 0.25 \mathrm{~A}$ & $4.21 \pm 0.21 \mathrm{a}$ & $3.83 \pm 0.21 \mathrm{~A}$ \\
\hline \multirow[t]{3}{*}{ Buram-3-ho } & 1 & $5.17 \pm 0.13 \mathrm{a}^{*}$ & $4.62 \pm 0.20 \mathrm{~A}$ & $3.88 \pm 0.18 \mathrm{a}$ & $4.04 \pm 0.28 \mathrm{~A}$ \\
\hline & 3 & $5.35 \pm 0.09 \mathrm{a}$ & $5.06 \pm 0.28 \mathrm{~A}$ & $3.83 \pm 0.03 \mathrm{a}$ & $3.83 \pm 0.10 \mathrm{~A}$ \\
\hline & 5 & $4.72 \pm 0.08 b$ & $4.56 \pm 0.20 \mathrm{~A}$ & $4.05 \pm 0.13 \mathrm{a}$ & $4.04 \pm 0.10 \mathrm{~A}$ \\
\hline
\end{tabular}

${ }^{\mathrm{a}} \mathrm{DAS}$; days after stress treatment

${ }^{b}$ Bacterial colonization was determined by counting colony-forming unit (cfu) in pot soils at 1, 3,5 d after stress treatment on Chinese cabbage plants.

${ }^{\mathrm{c}}$ Mean \pm standard errors with same letters are not significantly different between DAS at each non-stress or stresses in cultivars according to the least significantly difference test at $P<0.05$. An asterisk indicates significant difference between non-stress vs. stresses at each DAS according to the t-test. Experiments were conducted twice with four replicates each. 
compared to the non-stress conditions; H30-3 Rif did at 3 DAS. In 'Buram-3-ho', H26-2 Rif reduced colonization at 1 DAS under the stress conditions compared to non-stress condition (Table 1). Strain H26-2 and H30-3 did not drastically affect rhizosphere colonization during stresses and they maintained their populations. Similarly, Sherameti et al. (2008) found that root colonization by microorganisms can play a pivotal role for increasing plant growth and productivity under non-optimal environmental conditions. Moreover, like our strains, EPS-producing bacteria can effectively colonize roots and increase the stability of rootadhering soils. Santaella et al. (2008) revealed that the EPS of Rhizobium sp. YAS34 are targeted to specific parts of roots and they are critical to root colonization.

To determine the effect of bacterial EPS on plant tolerance to abiotic stresses, EPS of H26-2 and H30-3 were tested in plate assay and in planta. In the plate assay in MS media amended with mannitol, cultivars did not affect cotyledon greening $(P=0.2485)$ and number of lateral root $(P=0.1191)$ (Table 2). In 'Ryeokkwang', treatment did not show significant difference in cotyledon greening and number of lateral root, however, in 'Buram-3-ho', treatment show statistical significance in cotyledon greening $(P$ $=0.0231)$ and number of lateral root $(P=0.0494)$ (Table 2). In 'Buram-3-ho' EPS of H26-2 increased cotyledon greening and EPS of H30-3 promoted number of lateral root compared to a control (Table 2). In planta, cultivars did not affect fresh weight $(P=0.2937)$ under non-stress condition, however, showed significant difference on leaf wilting score $(P<0.0001)$ and fresh weight $(P=0.0006)$ after re-watering under stress conditions (Table 2). In 'Ryeokkwang', treatments including control, EPS of H262, and EPS of H30-3 had influenced on only fresh weight $(P$ $=0.0491$ ) after re-watering under stress conditions (Table 2). EPS of H30-3 statistically recovered fresh weight compared to a control but leaf wilting scores were not different

Table 2. Effect of exopolysaccharides of H26-2 and H30-3 on cotyledon greening (\%) and number of lateral roots after germination in plate assay, and fresh weight and leaf wilting score in Chinese cabbage under non-stressed or heat and drought stressed conditions

\begin{tabular}{|c|c|c|c|c|c|}
\hline \multirow{3}{*}{$\begin{array}{l}\text { Cultivars, } \\
\text { treatments }\end{array}$} & \multicolumn{2}{|c|}{ In plate assay $^{\mathrm{a}}$} & \multicolumn{3}{|l|}{ In planta ${ }^{\mathrm{b}}$} \\
\hline & \multicolumn{2}{|c|}{$\begin{array}{l}\text { (MS media amended with } \\
400 \mathrm{mM} \text { mannitol) }\end{array}$} & \multirow{2}{*}{$\begin{array}{c}\text { Non-stress } \\
\text { Fresh weight } \\
(\mathrm{g})\end{array}$} & \multicolumn{2}{|l|}{ Stresses } \\
\hline & $\begin{array}{c}\text { Cotyledon greening } \\
(\%)\end{array}$ & $\begin{array}{l}\text { Number of } \\
\text { lateral root }\end{array}$ & & $\begin{array}{l}\text { Leaf wilting score } \\
\qquad(0-5)\end{array}$ & $\begin{array}{l}\text { Fresh weight } \\
\text { (g) }\end{array}$ \\
\hline Cultivars & $\begin{array}{c}F \text { value }=1.37 \\
P \text { value }=0.2485\end{array}$ & $\begin{array}{c}F \text { value }=2.50 \\
P \text { value }=0.1191\end{array}$ & $\begin{array}{c}F \text { value }=1.13 \\
P \text { value }=0.2937\end{array}$ & $\begin{array}{c}F \text { value }=25.30 \\
P \text { value }<0.0001\end{array}$ & $\begin{array}{c}F \text { value }=13.53 \\
P \text { value }=0.0006\end{array}$ \\
\hline Ryeokkwang & $67.5 \pm 4.8 \mathrm{a}$ & $7.5 \pm 0.4 \mathrm{a}$ & $8.8 \pm 0.8 \mathrm{a}$ & $4.2 \pm 0.1 \mathrm{a}$ & $1.0 \pm 0.1 \mathrm{~b}$ \\
\hline $\begin{array}{l}\text { Buram-3-ho } \\
\text { Ryeokkwang }\end{array}$ & $75.4 \pm 4.7 \mathrm{a}$ & $6.8 \pm 0.3 \mathrm{a}$ & $7.8 \pm 0.6 \mathrm{a}$ & $2.9 \pm 0.2 b$ & $3.3 \pm 0.6 \mathrm{a}$ \\
\hline Treatments & $\begin{array}{c}F \text { value }=0.58 \\
P \text { value }=0.5732\end{array}$ & $\begin{array}{c}F \text { value }=0.79 \\
P \text { value }=0.4644\end{array}$ & $\begin{array}{c}F \text { value }=0.32 \\
P \text { value }=0.7326\end{array}$ & $\begin{array}{c}F \text { value }=0.18 \\
P \text { value }=0.8370\end{array}$ & $\begin{array}{c}F \text { value }=3.49 \\
P \text { value }=0.0491\end{array}$ \\
\hline Control & $67.5 \pm 5.3 \mathrm{a}$ & $6.5 \pm 0.3 \mathrm{a}$ & $9.6 \pm 1.5 \mathrm{a}$ & $4.1 \pm 0.1 \mathrm{a}$ & $0.8 \pm 0.1 \mathrm{~b}$ \\
\hline EPS of H26-2 & $75.0 \pm 11.2 \mathrm{a}$ & $6.6 \pm 0.5 \mathrm{a}$ & $8.9 \pm 1.3 \mathrm{a}$ & $4.1 \pm 0.1 \mathrm{a}$ & $1.0 \pm 0.1 \mathrm{ab}$ \\
\hline $\begin{array}{l}\text { EPS of H30-3 } \\
\text { Buram-3-ho }\end{array}$ & $60.0 \pm 12.7 \mathrm{a}$ & $7.3 \pm 0.6 \mathrm{a}$ & $8.1 \pm 1.3 \mathrm{a}$ & $4.2 \pm 0.1 \mathrm{a}$ & $1.3 \pm 0.2 \mathrm{a}$ \\
\hline Treatments & $\begin{array}{c}F \text { value }=4.53 \\
P \text { value }=0.0231\end{array}$ & $\begin{array}{c}F \text { value }=2.95 \\
P \text { value }=0.0494\end{array}$ & $\begin{array}{c}F \text { value }=0.01 \\
P \text { value }=0.9860\end{array}$ & $\begin{array}{c}F \text { value }=4.00 \\
P \text { value }=0.0337\end{array}$ & $\begin{array}{c}F \text { value }=5.03 \\
P \text { value }=0.0164\end{array}$ \\
\hline Control & $65.0 \pm 5.6 \mathrm{~b}$ & $6.5 \pm 0.4 \mathrm{a}$ & $8.0 \pm 1.0 \mathrm{a}$ & $3.8 \pm 0.2 \mathrm{a}$ & $1.1 \pm 0.4 \mathrm{~b}$ \\
\hline EPS of H26-2 & $90.0 \pm 10.0 \mathrm{a}$ & $7.6 \pm 0.5 \mathrm{ab}$ & $7.8 \pm 0.9 \mathrm{a}$ & $2.8 \pm 0.4 \mathrm{ab}$ & $4.0 \pm 1.0 \mathrm{a}$ \\
\hline EPS of H30-3 & $90.0 \pm 5.6 \mathrm{a}$ & $8.4 \pm 0.7 b$ & $7.7 \pm 1.2 \mathrm{a}$ & $2.3 \pm 0.5 \mathrm{~b}$ & $4.8 \pm 1.1 \mathrm{a}$ \\
\hline
\end{tabular}

${ }^{a}$ The numbers of seedlings with open and green leaves after seed germination were recorded at 3 and $4 \mathrm{~d}$ after seeding in repeated experiments; number of lateral root was evaluated at $17 \mathrm{~d}$ after seeding. Values \pm standard errors of each cultivar and treatment in a column followed by same letters are not significantly different according to the least significant difference test at $P<0.05$. Experiment were conducted twice with ten replicates each.

${ }^{b}$ Plants were treated with EPS $(10 \mu \mathrm{g} / \mathrm{ml})$ of strains $\mathrm{H} 26-2$ and $\mathrm{H} 30-3$, and $10 \mathrm{mM} \mathrm{MgSO}$ solution (control), one week later, heat and drought stress were treated; $24 \mathrm{~h}$ after end of stress treatment, leaf wilting score was assessed, and fresh weight after re-watering was assessed. Values \pm standard errors of each treatment in a column followed by same letters are not significantly different according to the least significant difference test at $P<0.05$. Experiments were conducted twice with eight replicates each. 
(Table 2). In 'Buram-3-ho', treatments showed significance at leaf wilting score $(P=0.0337)$ and fresh weight $(P=$ $0.0164)$ after re-watering under stress conditions. Treatment of EPS of H30-3 reduced leaf wilting and after re-wa- tering, EPS of two tested strains promote recovery of fresh weight in 'Buram-3-ho' (Table 2). However, EPS of H26-2 and H30-3 did not affect plant growth in non-stress conditions in both cultivars (Table 2). Bacterial EPS can protect

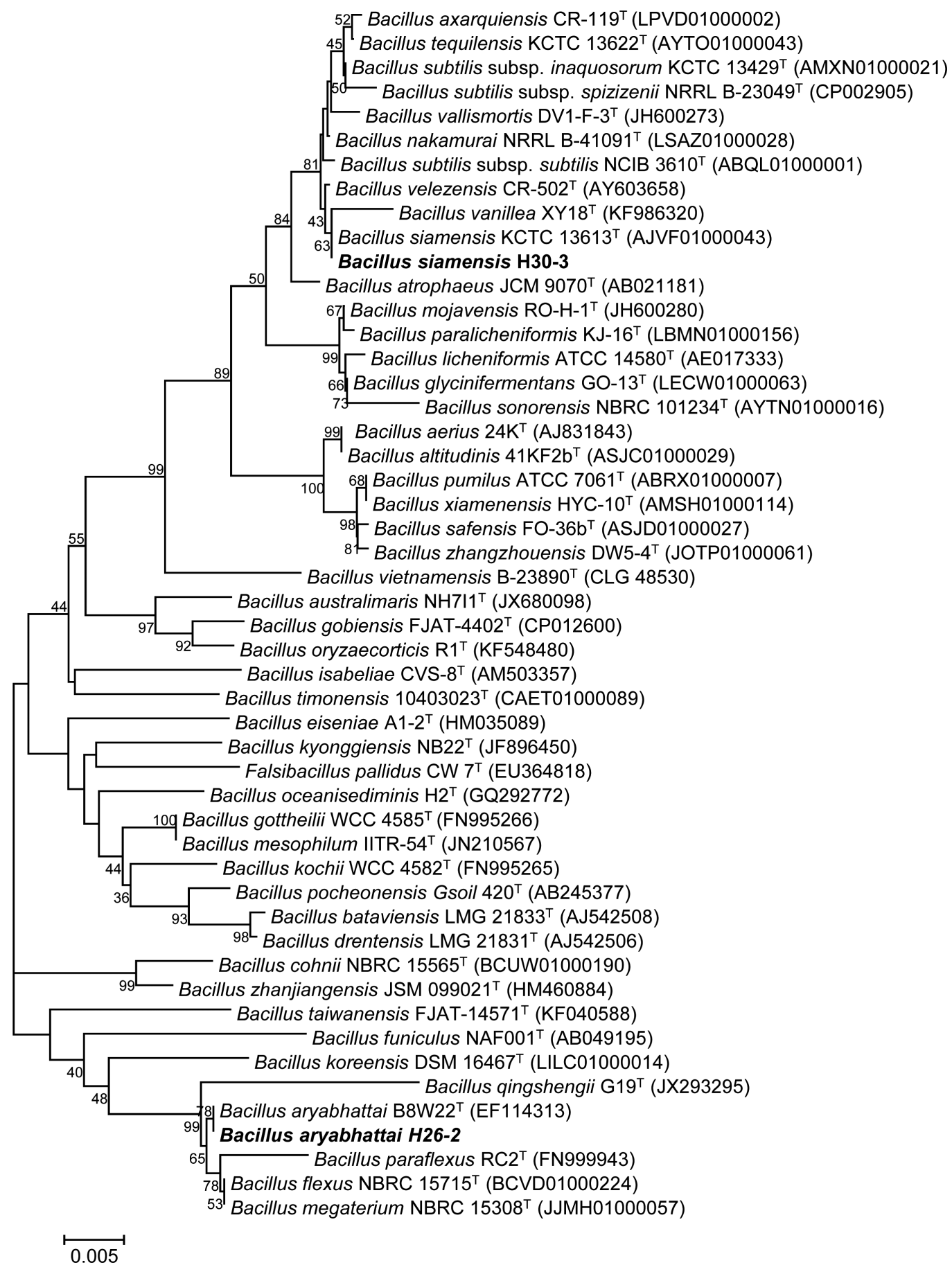

Fig. 3. A phylogenetic tree performed by the neighbor-joining method showing the relationship of Bacillus aryabhattai H26-2 and Bacillus siamensis H30-3 with other species of the genus Bacillus based on 16S rRNA sequences analysis. Numbers at the blanching points are the bootstrap values ( $>50 \%)$ for 1,000 replicates. A scale bar indicates 5 nucleotide substitutions per 1000 nucleotides of the sequence. Strains H26-2 and H30-3 are shown in bold type. T, type strain. 
microorganisms from water stress by enhancement of water retention and regulation of diffusion (Chenu and Roberson, 1996); they also help to attach and colonize the roots (Bashan and Hoguin, 1997). Exopolysaccharides released into the soil by EPS-producing bacteria can form a protective capsule around soil aggregates and plants can increase water deficit tolerance under drought conditions (Sandhya et al., 2009). In sand amended with purified EPS, water content was considerably higher than that in untreated controls at a low water potential and bacterial EPS dissolved nutrients in the bacterial microenvironment during drought stress. Therefore, soil treated with EPS dries more slowly compared with controls under drought stress (Alami et al., 2000). These results suggest that EPS can hold water in the surrounding microenvironment during drought stress, buffering against changes during abiotic stresses. Our results showed that EPS of strain H30-3 effectively reduced leaf wilting under heat and drought stresses and helped plants to recover after re-watering in 'Buram-3-ho' Chinese cabbage. In 'Ryeokkwang', extracted EPS of the two strains did not mitigate leaf wilt. Our results suggest that EPS of strain H30-3 can cause cultivar-dependent responses to heat and drought stresses in Chinese cabbage, indicating that EPS of strains H26-2 or H30-3 can interact with plants specifically. On the other hand, tested bacterial EPS did not affect plant growth in non-stress conditions. Therefore, EPS of H30-3 can be one of bacterial determinants for alleviating heat and drought stresses.

Strain H30-3 significantly reduced incidence of soft rot caused by $P$. carotovorum subsp. carotovorum PCC 21 only in 'Buram-3-ho', however, strain H26-2 did not show biocontrol activity against soft rot in both cultivars of Chinese cabbages. As similar results of effects of EPS on heat and drought stresses, strain H30-3 showed cultivar-different response to soft rot suppression. In our further study, whether EPS or other bacterial determinants of strain H30-3 can cause cultivar-different response to disease suppression; how to specify and recognize cultivar will be studied.

Strains H26-2 and H30-3 were identified as Bacillus aryabhattai, and B. siamensis, respectively, based on $16 \mathrm{~S}$ rRNA sequence analysis (data not shown). Strain H26$2(1,511 \mathrm{bp})$ showed $100 \%$ similarity to $B$. aryabhattai B8W22 ${ }^{\mathrm{T}}$ (EF114313); strain H30-3 (1,381 bp) exhibited $99.93 \%$ similarity to $B$. siamensis KCTC $13613^{\mathrm{T}}$ (AJVF01000043). These strains were deposited as B. aryabhattai $\mathrm{H} 26-2$ (KACC 92165P) and B. siamensis H303 (KACC 92187P) in the Korean Agricultural Culture Collection (KACC) of the National Institute of Agricultural Biotechnology (Wanju, Korea). Among diverse PGPR, $B a$ cillus spp. are widely known as potential candidates for tol-
Table 3. Biocontrol activity of tested bacterial strains against soft rot caused by Pectobacterium carotovorum subsp. carotovorum PCC21 in two cultivars of Chinese cabbages

\begin{tabular}{lll}
\hline \multirow{2}{*}{ Treatment } & \multicolumn{2}{c}{ Disease incidence (\%) } \\
& Ryeokkwang & Buram-3-ho \\
Control & $60.0 \pm 4.7 \mathrm{ab}$ & $72.0 \pm 6.8 \mathrm{a}$ \\
BTH & $46.0 \pm 8.5 \mathrm{~b}$ & $46.0 \pm 7.9 \mathrm{~b}$ \\
H26-2 & $62.0 \pm 8.7 \mathrm{ab}$ & $60.0 \pm 8.4 \mathrm{ab}$ \\
H30-3 & $70.0 \pm 7.5 \mathrm{a}$ & $40.0 \pm 7.9 \mathrm{~b}$ \\
\hline
\end{tabular}

${ }^{\mathrm{a}}$ Values \pm standard errors of treatments in a column followed by same letters are not significantly different according to the least significant difference test at $P<0.05$. Experiment was conducted twice with three replicates with 15 seedling each.

erance against abiotic stresses such as drought and extreme temperature (Tiwari et al., 2017). They have structural and physiological advantages including a multi-layered cell wall and secretion of various antibiotics, peptides, signal molecules, and extracellular enzymes. These traits can help their survival under different environmental stress conditions for a long period (Kumar et al., 2012). Bacterial structural characters, such as the thick cell walls of Bacillus species and EPS production, could act to maintain populations under stress conditions.

Taken together, our results suggest that $B$. aryabhattai H26-2 and B. siamensis H30-3 have effects on both plant growth promotion and alleviation of heat and drought stresses in Chinese cabbage. To cope with the stresses, strains H26-2 and H30-3 reduced leaf wilting by increasing ABA contents and reducing stomatal opening in Chinese cabbages. Moreover, the two strains were not altered for colonization in the rhizosphere and maintained their population during stresses. According to our results, EPS of strain H30-3 might interact with Chinese cabbages cultivar specifically, and it is pivotal one of bacterial determinants in mitigating heat and drought stresses in 'Buram3-ho' Chinese cabbage. As well as mitigation of abiotic stresses, strain H30-3 could reduce soft rot incidence (\%) in 'Buram-3-ho' Chinese cabbage. Further studies to elucidate the mechanisms related to physiological and transcriptional changes in plants and cultivar-dependent response by strain H30-3 will be studied to better understand mitigation of abiotic and biotic stresses conferred by plant-bacteria interactions.

\section{Acknowledgment}

This work was supported by National Institute of Agricultural Science (Project No. PJ012517) of Rural Development Administration, Republic of Korea. 


\section{References}

Alami, Y., Achouak, W., Marol, C. and Heulin, T. 2000. Rhizosphere soil aggregation and plant growth promotion of sunflowers by an exopolysaccharide-producing Rhizobium sp. strain isolated from sunflower roots. Appl. Environ Microbiol. 66:3393-3398.

Barnawal, D., Bharti, N., Maji, D., Chanotiya, C. S. and Kalra, A. 2014. ACC deaminase-containing Arthrobacter protophormiae induces $\mathrm{NaCl}$ stress tolerance through reduced ACC oxidase activity and ethylene production resulting in improved nodulation and mycorrhization in Pisum sativum. J. Plant Physiol. 171:884-894.

Barrs, H. D. and Weatherley, P. E. 1962. A re-examination of the relative turgidity technique for estimating water deficit in leaves. Aust. J. Biol. Sci. 15:413-428.

Bashan, Y. and Holguin, G. 1997. Azospirillum-plant relationships: environmental and physiological advances. Can. J. Microbiol. 43:103-121.

Belimov, A. A., Dodd, I. C., Hontzeas, N., Theobald, J. C., Safronova, V. I. and Davies, W. J. 2009. Rhizosphere bacteria containing 1-aminocyclopropane-1-carboxylate deaminase increase yield of plants grown in drying soil via both local and systemic hormone signalling. New Phytol. 181:413-423.

Bresson, J., Varoquaux, F., Bontpart, T., Touraine, B. and Vile, D. 2013. The PGPR strain Phyllobacterium brassicacearum STM196 induces a reproductive delay and physiological changes that result in improved drought tolerance in Arabidopsis. New Phytol. 200:558-569.

Bric, J. M., Bostock, R. M. and Silverstone, S. E. 1991. Rapid in situ assay for indole acetic acid production by bacteria immobilized on a nitrocellulose membrane. Appl. Environ. Microbiol. 57:535-538.

Castric, K. F. and Castric, P. A. 1983. Method for rapid detection of cyanogenic bacteria. Appl. Environ. Microbiol. 45:701702.

Chenu, C. and Robersin, E. B. 1996. Diffusion of glucose in microbial extracellular polysaccharide as affected by water potential. Soil Biol. Biochem. 28:877-884.

Dimkpa, C., Weinand, T. and Asch, F. 2009. Plant-rhizobacteria interactions alleviate abiotic stress conditions. Plant Cell Environ. 32:1682-1694.

Dobra, J., Motyka, V., Dobrev, P., Malbeck, J., Prasil, I. T., Haisel, D., Gaudinova, A., Havlova, M., Gubis, J. and Vankova, R. 2010. Comparison of hormonal responses to heat, drought and combined stress in tobacco plants with elevated proline content. J. Plant Physiol. 167:1360-1370.

Ghosh, D., Sen, S. and Mohapatra, S. 2017. Modulation of proline metabolic gene expression in Arabidopsis thaliana under water-stressed conditions by a drought-mitigating Pseudomonas putida strain. Ann. Microbiol. 67:655-668.

Jung, S. S., Jeong, H. H. and Kim, K. S. 2000. Effects of uniconazole treatment on the growth and flowering of potted Chry- santhemum indicum L. Korean J. Hortic. Sci. Technol. 18:2832.

Lee, S. H. and Cha, J. S. 2001. Efficient induction of bacterial soft rot using mineral oil. Phytopathology 91:S53-S54.

Levene, H. 1960. Robust tests for equality of variances. In: Contributions to prorobability and statistics: Essays in honor of harold hotelling, eds. by I. Olkin, S. G. Ghurye, W. Hoeffding, W. G. Madow and H. B. Mann, pp. 278-292. Stanford University Press, Stanford, California, USA.

Kang, S.-M., Radhakrishnan, R., Khan, A. L., Kim, M.-J., Park, J.-M., Kim, B.-R., Shin, D.-H. and Lee, I.-J. 2014. Gibberellin secreting rhizobacterium, Pseudomonas putida $\mathrm{H}-2-3$ modulates the hormonal and stress physiology of soybean to improve the plant growth under saline and drought conditions. Plant Physiol. Biochem. 84:115-124.

Kaushal, M. and Wani, S. P. 2016. Plant-growth-promoting rhizobacteria: drought stress alleviators to ameliorate crop production in drylands. Ann. Microbiol. 66:35-42.

Khandelwal, A. and Sindhu, S. S. 2013. ACC deaminase containing rhizobacteria enhance nodulation and plant growth in clusterbean (Cyamopsis tetragonoloba L.). J. Microbiol. Res. $3: 117-123$.

Kim, C.-G., Lee, S.-M., Jeong, H.-K., Jang, J.-K., Kim, Y.-H. and Lee, C.-K. 2010. Impacts of climate change on Korean agriculture and its counterstrategies. Korea Rural Economic Institute, Seoul, Korea. 305 pp.

Kim, H.-S., Sang, M. K., Myung, I. S., Chun, S. C. and Kim, K. D. 2009. Characterization of Bacillus luciferensis strain KJ2C12 from pepper root, a biocontrol agent of Phytophthora blight of pepper. Plant Pathol. J. 25:62-69.

Kumar, A., Kumar, A., Devi, S., Patil, S., Payal, C. and Negi, S. 2012. Isolation, screening and characterization of bacteria from rhizospheric soils for different plant growth promotion (PGP) activities: an in vitro study. Recent Res. Sci. Technol. 4:1-5.

Milagres, A. M. F., Machuca, A. and Napoleão, D. 1999. Detection of siderophore production from several fungi and bacteria by a modification of chrome azurol S (CAS) agar plate assay. J. Microbiol. Methods 37:1-6.

Penrose, D. M. and Glick, B. R. 2003. Methods for isolating and characterizing ACC deaminase-containing plant growthpromoting rhizobacteria. Physiol. Plant. 118:10-15.

Pikovskaya, R. I. 1948. Mobilization of phosphorus in soil in connection with the vital activity of some microbial species. Microbiology 17:362-370.

Sandhya, V., Shaik, Z. A., Grover, M., Reddy, G. and Venkateswarlu, B. 2009. Alleviation of drought stress effects in sunflower seedlings by the exopolysaccharides producing Pseudomonas putida strain GAP-P45. Biol. Fert. Soils 46:1726.

Sang, M. K. and Kim, K. D. 2012. The volatile-producing Flavobacterium johnsoniae strain GSE09 shows biocontrol activity against Phytophthora capsici in pepper. J. Appl. Microbiol. 113:383-398. 
Sang, M. K., Jeong, J.-J., Kim, J. and Kim, K. D. 2018. Growth promotion and root colonization in pepper plants by phosphate-solubilising Chryseobacterium sp. strain ISE14 that suppresses Phytophthora blight. Ann. Appl. Biol. 172:208223.

Santaella, C., Schue, M., Berge, O., Heulin, T. and Achouak, W. 2008. The exopolysaccharide of Rhizobium sp. YAS34 is not necessary for biofilm formation on Arabidopsis thaliana and Brassica napus roots but contributes to root colonization. Environ. Microbiol. 10:2150-2163.

Sherameti, I., Tripathi, S., Varma, A. and Oelmüller, R. 2008. The root-colonizing endophyte Pirifomospora indica confers drought tolerance in Arabidopsis by stimulating the expression of drought stress-related genes in leaves. Mol. PlantMicrobe. Interact. 21:799-807.

Singh, R. P. and Jha, P. N. 2016. The Multifarious PGPR Serratia marcescens CDP-13 augments induced systemic resistance and enhanced salinity tolerance of wheat (Triticum aestivum. L.). PLoS One 11:e0155026.

Tallgren, A. H., Airaksinen, U., Von Weissenberg, R., Ojamo, H., Kuusisto, J. and Leisola, M. 1999. Exopolysaccharide-producing bacteria from sugar beets. Appl. Environ. Microbiol. 65:862-864.

Timmusk, S., Abd El-Daim, I. A., Copolovici, L., Tanilas, T., Kännaste, A., Behers, L., Nevo, E., Seisenbaeva, G., Stenström, E. and Niinemets, Ü. 2014. Drought-tolerance of wheat improved by rhizosphere bacteria from harsh environments: enhanced biomass production and reduced emissions of stress volatiles. PLoS One 9:e96086.
Tiwari, S., Prasad, V., Chauhan, P. S. and Lata, C. 2017. Bacillus amyloliquefaciens confers tolerance to various abiotic stresses and modulates plant response to phytohormones through osmoprotection and gene expression regulation in rice. Front. Plant Sci. 8:1510.

Vurukonda, S. S., Vardharajula, S., Shrivastava, M. and Shaik, Z. A. 2016. Enhancement of drought stress tolerance in crops by plant growth promoting rhizobacteria. Microbiol. Res.184:1324.

Weisburg, W. G., Barns, S. M., Pelletier, D. A. and Lane, D. J. 1991. 16S ribosomal DNA amplification for phylogenetic study. J. Bacteriol. 173:697-703.

Yang, J., Kloepper, J. W. and Ryu, C. M. 2009. Rhizosphere bacteria help plants tolerate abiotic stress. Trends Plant Sci. 14:14.

Yoon, S. H., Ha, S. M., Kwon, S., Lim, J., Kim, Y., Seo, H. and Chun, J. 2017. Introducing EzBioCloud: A taxonomically united database of 16S rRNA and whole genome assemblies. Int. J. Syst. Evol. Microbiol. 67:1613-1617.

Zhang, H., Mao, X., Wang, C. and Jing, R. 2010. Overexpression of a common wheat gene TaSnRK2.8 enhances tolerance to drought, salt and low temperature in Arabidopsis. PLoS One 5:e16041.

Zhang, J., Jia, W., Yang, J. and Ismail, A. M. 2006. Role of ABA in integrating plant responses to drought and salt stresses. Field Crops Res. 97:111-119.

Zhu, J.-K. 2002. Salt and drought stress signal transduction in plants. Annu. Rev. Plant Biol. 53:247-273. 